\title{
A Different Way of Thinking about the Two-State Solution
}

\author{
Jerome M. Segal
}

$\mathrm{I}_{\mathrm{A}}^{\mathrm{n}}$ n November of 1947, the United Nations General Assembly passed what came to be called "The Partition Resolution" (UNGA Res. 181). The Partition Resolution sought to resolve the Zionist-Palestinian struggle by ending the British Mandate for Palestine, and by bringing into existence, in the words of the resolution, "independent Arab and Jewish States." The land administered by Great Britain was to be divided between the two states. Unfortunately, rather than peace, the immediate result was the 1948 war. For many decades afterwards, few believed that peace could be obtained by returning to the two-state idea. Today, however, we seem to have come full circle, and there is currently a broad international consensus that the solution to the Israeli-Palestinian conflict is to be found in the "two-state solution." While they disagree extensively on the specifics, both the Palestine Liberation Organization (PLO) and the present government of Israel, headed by Prime Minister Benyamin Netanyahu, at least verbally are part of this consensus-that the central outcome of peace negotiations will be the establishment of a Palestinian state that will live in peace alongside the State of Israel.

Paradoxically, the very period during which the twostate consensus has taken hold has been a period of failed negotiations, first the Camp David negotiations in the summer of 2000, then the failed Taba negotiations in January 2001, and most recently the failed Annapolis round of negotiations in 2007-2008. As a result there are many who, while believing the twostate solution necessary, have come to wonder whether it is possible. Outstanding issues include borders, the genuineness of Palestinian sovereignty, provisions to protect Israeli security, Jerusalem, Israeli settlements in the West Bank, and Palestinian refugees. It is not clear how best to proceed. Some suggest that a totally different solution needs to be found (e.g., a one-state solution). Others believe that one more round of negotiations, with active American engagement, can reach a solution. Unexplored, however, is whether there is another path: rather than rejecting the twostate idea altogether, and rather than merely pushing forward along well-worn tracks, perhaps we should consider whether there might be an alternative way of conceiving of the two-state solution.

The starting point for such an approach is an awareness of the implicit model that has dominated the negotiations thus far. Broadly speaking, but especially for Israelis, the understanding of how those two states will interact is one of strict separation: "we are here and they are there."

For Israelis, strict separation is represented by the wall, or "separation fence," that was constructed to block access from much of the West Bank to Israel, East Jerusalem, and key settlements. It is further reflected in the Israeli determination that no Palestinian refugees will return to Israel, certainly none "by right." On the Palestinian side, the strictseparation vision is also widely held. It is expressed in the Palestinian determination that aside from minor swaps, all Jewish settlements will be evacu-

The attachment to the strict-separation paradigm of the two-state solution is so pervasive that at times it leads to a confusion between the idea of two states and the idea of two homelands.

ated from whatever land becomes sovereign Palestinian territory, and in the desire for sharp, straight-line borders, Palestinian airports, and economic independence.

The attachment to the strict-separation paradigm of the two-state solution is so pervasive that at times it leads to a confusion between the idea of two states and the idea of two homelands. For instance, in the Clinton Parameters we find the statement, "A new State of Palestine is about to be created as the homeland of the Palestinian people, just as Israel was established as the homeland of the Jewish people." Similarly, in the Geneva Accords, a peace agreement 
text developed by Israelis and Palestinians in a nonofficial capacity, we also find the two-state idea intermingled with a two-homeland idea: "The parties recognize Palestine and Israel as the homelands of their respective peoples."

This is a confusion. The concept of "homeland" is quite different from that of "state." States are political constructions: they are created at specific points in time as the result of deliberate acts of human decision-making. But a homeland is a different matter. A geographical region is the homeland of a people, not through a

A geographical region is the homeland of a people, not through a political decision, but in virtue of a people's history and cultural self-identification.

political decision, but in virtue of a people's history and cultural self-identification. It is the area in which a people emerged or flourished and that plays a central role in their own understanding of themselves. To call a place one's homeland is to say something important about oneself and about how one understands oneself in relation to the history of the people with which one identifies. Thus, for Palestinians, while a peace agreement may establish the West Bank and Gaza as the territory of the Palestinian State, such an agreement cannot undo the fact that all of historic Palestine is the homeland of the Palestinian people. Similarly, no political decision or document can change the fact that the historic homeland of the Jewish people does not neatly mirror the borders of the State of Israel.

The confusion between state and homeland occurs, in part, because the same term is often used to refer to both. For instance, "France" may be used to refer to the land of France, the region from which the French people emerged and over which the State of France exercises sovereignty. But "France" is also used to refer to the State of France, which is essentially an artificial person, somewhat like a corporation (e.g., Exxon, AT\&T). France, in this sense, is an agent. It votes in the United Nations, is a member of NATO, and invaded Egypt in the 1956 Suez War. In part, the confusion occurs with respect to the Israeli-Palestinian conflict because things would be so much easier were it the case that by constructing two states, one could thereby construct two homelands, each co-existent with the sovereign region of each state. So motivated, there occurs what we might term "negotiators' hubris," in which those seeking to negotiate an end to the conflict slip into believing that a negotiated peace agreement can transform all problematic aspects of the underlying history. Alas, it is not so.
The distinction between homeland and state is most readily seen by looking at the Israeli Declaration of Independence. The declaration was issued on May 14, 1948, and in its operative paragraph states: "We . . representatives of the Jewish community of EretzIsrael and of the Zionist movement, ... here assembled on the day of the termination of the British Mandate over Eretz-Israel, ... hereby declare the establishment of a Jewish state in Eretz-Israel, to be known as the State of Israel." It was through this act, which declares that the State of Israel is "hereby" established, that the state came into being, on that day, at that time.

But the homeland, Eretz-Israel, the land of Israel, as the homeland of the Jewish people, preexisted the new state by several thousand years. And thus, the opening of the Declaration stated: "Eretz-Israel was the birthplace of the Jewish people. Here their spiritual, religious and political identity was shaped." And we are told, "Impelled by this historic and traditional attachment, Jews strove in every successive generation to reestablish themselves in their ancient homeland."

Quite analogously, the PLO Covenant, written in 1964, and speaking of much the same land, opens with the phrase, "Palestine is the homeland of the Palestinian Arab People." And in 1988, when the Palestinians issued their own Declaration of Independence, they matched the Israeli declaration paragraph by paragraph. Thus the Palestinian Declaration, which is somewhat more inclusive than

To call a place one's homeland is to say something important about oneself and about how one understands oneself in relation to the history of the people with which one identifies.

the Israeli declaration, opens with: "Palestine, the land of the three monotheistic faiths, is where the Palestinian Arab people was born, on which it grew, developed and excelled. The Palestinian people was never separated from or diminished in its integral bonds with Palestine. Thus the Palestinian Arab people ensured for itself an everlasting union between itself, its land and its history." We are told, "And in generation after generation, the Palestinian Arab people gave of itself unsparingly in the valiant battle for liberation and homeland." When referring to the creation of Israel in 1948 and to those Palestinians who did not become refugees, it describes them as "a vestige subjugated in its homeland." It is only after recounting Palestinian history in "defense of the freedom and independence of their homeland," that the declaration reaches its operative paragraph and "hereby proclaims the establishment of the State of Palestine." 


\section{Two Peoples, Two States, One Homeland}

The fact that the Jewish people and the Palestinian people, because of both history and identity, have one and the same territory as their common homeland does not dictate any particular answer to how the two states should relate to each other. It is quite possible to decide that, within the common homeland, there will be two strictly separated states. The problem, however, is that strict separation maximizes the sense of loss for both peoples. For the Israelis, especially those settlers motivated by national/religious convictions, there is the deeply disturbing fact that the central Biblical narratives are located in the hill country of the West Bank, not the coastal plain of Israel. It is in Hebron that Abraham and Sarah, Isaac and Rebecca and Jacob, are buried, not in the environs of Tel Aviv. Joseph's Tomb is in Nablus, Rachel's is outside Bethlehem. King David was born in Bethlehem.

For the Palestinians, the sense of loss is far more immediate and widespread. The right they affirm is not a vague return to "Palestine" or the State of Palestine. The return, in Palestinian consciousness and as articulated in UN General Assembly Resolution 194, is to their 1948 homes. Those homes, for the vast majority of the refugees, were in regions that are within Israel, not the West Bank. Thus, the creation of a Palestinian state on 22 percent of historic Palestine is not experienced by Palestinians as a triumph, but as the finalization (even if necessary) of their loss.

For both peoples, this sense of loss is buttressed by arguments about justice. On the Israeli side, those opposed to evacuating Jewish settlements in the West Bank invoke memories of the Holocaust. They ask, "How can an Israeli government accept that the core areas of their historic homeland will be "Judenrein"? It is further argued that if Jews have no right to live in

The creation of a Palestinian state on 22 percent of historic Palestine is not experienced

by Palestinians as a triumph, but as the finalization (even if necessary) of their loss.

Hebron, a cradle of the ancient Jewish presence in the Promised Land, then on what basis do they have a right to be in Tel Aviv? On the Palestinian side, whatever may or may not be required by the pragmatics of the current balance of forces, there is a broad and deep sense of injustice. Most Palestinians believe that they were the victims of a deliberate effort at ethnic cleansing, and they believe that international law guarantees them the right to return to their homes. In their view, if they have to accept something less, it is not because doing so is just, but because they are weak.
These issues have made it particularly difficult to negotiate a strict-separation agreement. Such an agreement will be hard to implement, and if implemented, it will be highly unstable. For instance:

Implementation. While Israeli negotiators have been willing to agree to the evacuation of most of the settlements in the West Bank, and one can be optimistic that agreement on the borders of a Palestinian state can be found, one can also have severe doubts about implementation. Will any Israeli government actually have

$$
\begin{gathered}
\text { Given that a two-state solution along the } \\
\text { strict-separation model does not have high } \\
\text { prospects of being negotiated, implemented, } \\
\text { and stabilized, it is worth investigating } \\
\text { whether there is a workable alternative model } \\
\text { of two states. }
\end{gathered}
$$

the ability to implement the removal of over 75,000 settlers from the central areas of the West Bank? What if a significant percentage of the settlers are prepared to resist their evacuation? Will Israel really fight its own people to fulfill its treaty commitments?

Sustainability. If Palestinian negotiators (the PLO leadership) accept an agreement that provides no accommodation of Palestinian claims with respect to a right of return, they will be subject to delegitimization. If a Palestinian state comes into existence on that basis, there is far greater likelihood that Hamas or some successor organization will come to power by winning the first or second democratic elections within that state. If that occurs, could a peace accord survive?

Negotiability. The political implications of abandoning refugee claims are well understood by the PLO leadership. Accordingly, in past negotiations they have sought from the Israelis some willingness to allow a credible number of refugees to return, as well as acceptance, in principle, of a general right to return. On the other hand, while Israeli positions on borders have become more forthcoming, in recent years the Israeli position on refugees has hardened. Today there is almost no willingness to allow the return of any refugees. Thus the strict-separation paradigm of the two-state solution faces major problems of negotiability.

Given that a two-state solution along the strict-separation model does not have high prospects of being negotiated, implemented, and stabilized, it is worth investigating whether there is a workable alternative model of two states. What would the two-state solu- 


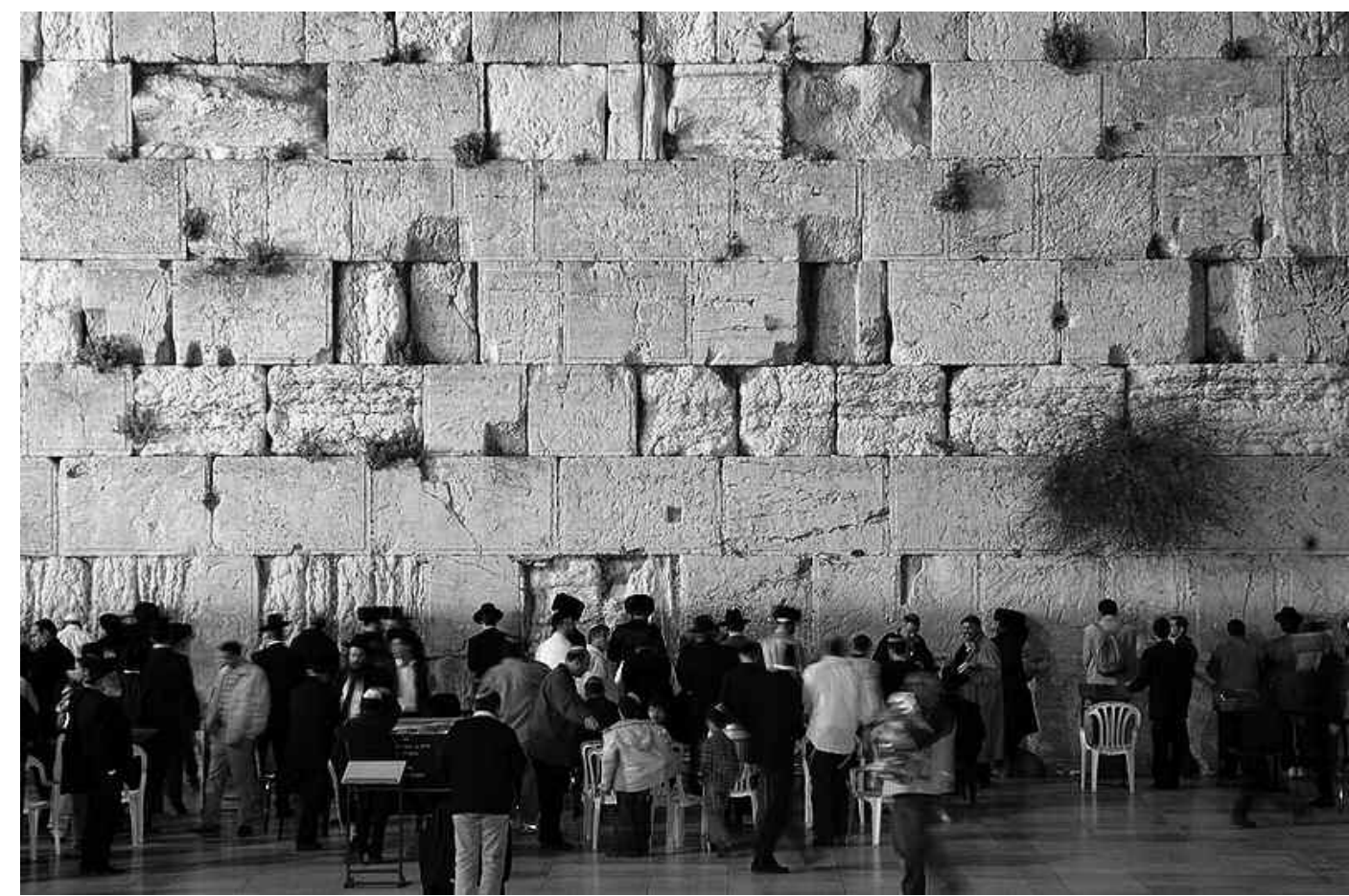

Western wall in Jerusalem (Wayne McLean, Creative Commons Attribution)

tion look like if rather than turning away from the underlying reality of the common homeland, we were to embrace that reality?

\section{A Common Homeland Approach to Two States}

Mutual Recognition of the Common Homeland: The heart of a peace agreement, rather than being the creation of two states, would be mutual recognition that all of the land between the Jordan River and the Mediterranean Sea is the common homeland of the two peoples. Thus, a peace agreement within the Common Homeland orientation might affirm: "All of historic Palestine, from the Jordan River to the Mediterranean, is the common homeland of the Jewish and Palestinian peoples. Though this homeland is to be divided into two distinct states, it is the intention of the two states to undertake agreements and policies that will respect and honor the oneness of the joint homeland, giving access to it to both peoples."

Whether or not it will be practicable to implement the common homeland perspective in the immediate future, it is important that it be clearly affirmed at the outset, as an essential part of how the two-state solution is conceptualized. Rather than building loss into the basic conceptualization of the two states, the focus should be on hope. To those elements on both sides that are most opposed to the peace process, it should be made clear that their aspiration to be able to live within the entirety of their historic homeland is most likely to be achieved in a peace that brings deep reconciliation between the two peoples.

Two States: Having accepted that there is only one homeland, and that it must be shared, the two sides would agree that at present, and perhaps into the indefinite future, the only practicable option is to

$$
\begin{gathered}
\text { Rather than building loss into the basic } \\
\text { conceptualization of the two states, the focus } \\
\text { should be on hope. }
\end{gathered}
$$

divide the homeland into two sovereign states, which, as characterized in UN General Assembly Resolution 181, are one Arab and one Jewish. The treaty, however, would hold out the possibility that over time, but only with the consent of both states, this pragmatic decision about two states could evolve into various possibilities including a confederation between the two states, or a single federated state that has two provinces, or even a single unitary state in which all are equal citizens. The parties would agree that peri- 


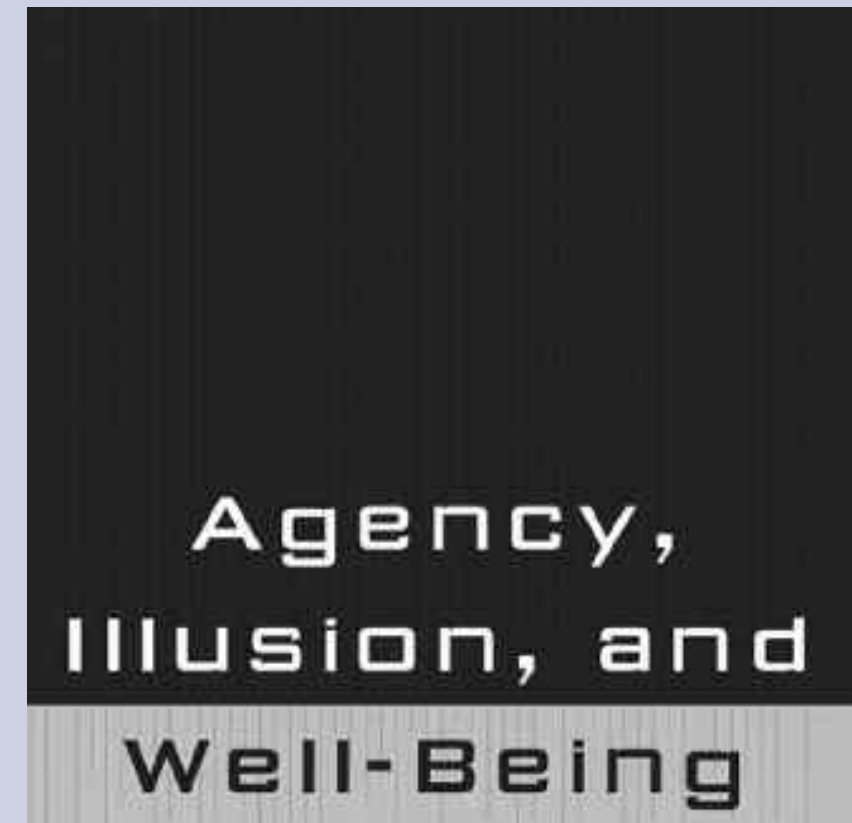



\section{Jerome M. Segal}

\author{
Lexington Books \\ A division of Rowman \& Littlefield Publishers, Inc. \\ 4501 Forbes Boulevard, Suite 200 \\ Lanham, Maryland 20706 \\ $1-800-462-6420$ \\ www.lexingtonbooks.com
}

\section{Agency, Illusion, and Well-Being}

\author{
Jerome M. Segal
}

Praise for Agency and Alienation

"Jerome M. Segal has made a major contribution to the phenomenology of action."

-Canadian Philosophical Review

"Agency and Alienation stretches the boundaries of current thought and debate in the philosophy of mind. It is a thought-provoking and original book."

—Michael Slote, University of Miami

"I would think that Jerome M. Segal's position would become in time one of the basic positions in the philosophy of action taught in graduate schools and referred to in the literature." -Terry P. Ponkard, Georgetown University

Praise for Graceful Simplicity

"A marvelously textured analysis of the elusive ideal of simple living. ... A must-read."

-David Shi, author of The Simple Life and president of Furman University

Praise for Joseph's Bones: Understanding the Struggle Between God and Mankind in the Bible

"A work of stunning originality. ... Nothing quite like it has appeared in years."

$$
\text { —Jack Miles, author of God: A Biography }
$$

Agency, Illusion and Well-Being is a collection of essays drawn from Jerome M. Segal's earlier books, including essays from Agency and Alienation, Joseph's Bones, and Graceful Simplicity. Arranged thematically into a coherent new whole, this selection of essays highlights Jerome M. Segal's contribution to philosophical economics and moral psychology in a definitive edition.

Jerome M. Segal is a senior research scholar at the University of Maryland's Institute for Philosophy and Public Policy. odically (e.g., every ten or fifteen years), they would convene to explore such possibilities, but that changes would require mutual consent.

Jerusalem: As a symbol of the oneness of the homeland, the Old City of Jerusalem would lie outside the realm of political sovereignty. It would be the joint possession of the two peoples, with the Temple Mount under Palestinian administration and the Western Wall under Israeli administration. Possibly, to emphasize the common religious roots of Judaism, Islam, and Christianity (the three Abrahamic religions), it would be affirmed that with respect to the Old City, sovereignty belongs only to God.

Citizenship/Residency: With respect to Jews wishing to live in the West Bank and Palestinians (whether refugees or not) wishing to live within Israel, it would be affirmed that within the two-state model, each state has the ultimate authority over the admission of noncitizens to the territory of its respective sovereignty. On that basis, however, the two states could decide to enter into any of a variety of experimental programs during a lengthy process of implementation.

Thus, as an example, it might be possible to take a settlement such as Ariel, which sits fairly deep within the West Bank, and while agreeing that the land it is on is the sovereign territory of the state of Palestine, the two sides might have a trial program in which Ariel will be matched with an area inside Israel, an area which is the traditional home of Palestinian refugees. Just as Israeli citizens will be allowed to continue to remain in Ariel, so too will refugees be allowed to return to live within a new 
community inside Israel, one linked to the Palestinian state through special access roads. Such an arrangement would be done on a trial basis. It would represent the hope that ways could be found to allow wider implementation of the right to live anywhere in the homeland. If, after several years, it is found that this is an unworkable idea, then both Ariel and the parallel area inside Israel would have to be evacuated.

Yet even this would not be permanent. After a decade of peace, after a cooling off period in which a new generation arose, it would remain possible again to explore the viability of this or other ideas to give meaningful expression to the oneness of the homeland.

Rights of Palestinian Refugees: Palestinian refugees would have a right to compensation for land that they owned in Israel prior to the 1948 War. As to their claimed right to return to Israel, this would be subsumed within a general right of all Palestinians and all Israelis to live anywhere within the homeland. As the implementation of this general right will be significantly restricted by the two states, priority would be given to the refugees, especially to those who actually were born in what is today Israel, as distinct from their descendants. And because the distinction will be made between residency and citizenship, trial programs would be developed to explore the viability of some refugees returning to Israel but as Palestinian citizens. Here the fact that even today 200,000 Palestinians live in Jerusalem but by choice are not citizens of Israel suggests that creative opportunities can be found. A peace treaty would not center on coming up with "an historic number" of refugees who would return. Rather, the pledge would be to maximize what was possible, based on experience with trial programs, as state-to-state relations evolved.

Security: With respect to some of the most vexing problems of security that concern Israelis (e.g., how can they be assured that ending the occupation will not mean rockets from the West Bank landing on Ben Gurion Airport?), answers must be found which respect Palestinian sovereignty and the equal dignity of the two states. One possibility within the common homeland model is that there could be a joint security force that has a presence along the entire external perimeter of the homeland. Thus, rather than having, as Israel seeks, Israeli troops on the border with Jordan, there could be a homeland force that would also patrol the borders with Lebanon, Syria, and Egypt. Again, this would be viewed as experimental, and if it failed, then the fallback would be strict separation between the two states with deterrence as the primary factor on which stability was grounded, but the aspiration would be for cooperation.
Integration: Economically, the common homeland approach would pursue the goals of the original Partition Resolution of 1947 (UNGA 181), articulated in the section on "Economic Union and Transit," including a customs union, a joint currency that would replace the Israeli shekel, common railways, shared ports and airports, as well as "freedom of transit and visit for all residents or citizens of both States." As noted in Resolution 181, such freedoms would be subject to security considerations, but with genuine peace, both states would be fully open to both peoples. The extant remains of the four hundred Palestinian villages bulldozed in 1948 could be turned over to a Homelands Historical Commission, part of the project of remembering rather than obscuring the tragic history of the struggle for exclusivity within the common homeland.

Education: Finally and of great importance, the common homeland perspective would emphasize education that would promote the future ability of the two peoples genuinely to share the same land. This would require a willingness on the part of both societies to open themselves to learning how the other side understands itself and understands the history of the conflict. Neither side would seek to control the curriculum of the other, but both would agree to allow their youth to learn first hand, from the other, their very different perspectives.

\section{Conclusions}

At the present moment the relations between the two peoples are a far distance from what is required to achieve what I have just described. But it would be a mistake to dismiss this as naïve. What is presented here is an ideal to which the parties would pledge themselves. If we think of the peace negotiations as historic, then we must recognize that in the relations between the two states there will be ups and downs. And even if at the outset it is decided to operate along the lines of strict separation, the common homeland orientation expresses an intention to achieve a future in which the two peoples could truly share their common homeland.

Jerome M. Segal

Director, Peace Consultancy Project

Institute for Philosophy and Public Policy

jsegal@umd.edu 